\title{
The Impact of Air and Noise Pollution on Health Status in Turkey: A Willingness to Pay Approach
}

$\ddot{O}_{z \text { nur }}$ ÖZDAMAR, Department of Econometrics, Aydin Faculty of Economics, Adnan Menderes University, Turkey; e-mail: oznur.ozdamar@adu.edu.tr

Eleftherios GIOVANIS, Department of Economics, University of Verona, Italy; e-mail:

eleftherios.giovanis@univr.it

\section{Türkiye'de Hava ve Gürülttü Kirliliğinin Sağlık Durumu Üzerindeki Etkisi: Gönül Rızasıyla Ödeme Yaklaşımı}

\begin{abstract}
This study analyses the determinants of health status and the willingness to pay for a reduction in air and noise pollution in Turkey over the period 2006-2012. The analysis relies on a pseudo-panel data using age and region cohorts. Furthermore, we follow the instrumental variables (IV) approach and we apply the two and three stage least squares methods using wind direction and regional complaint rates on pollution as instruments. Based on our favoured estimates, individuals who report problems with air and noise pollution are willing to pay for an improvement in air and noise quality more by 20.00-25.00 Turkish Liras (TL) per month.
\end{abstract}

Keywords

Air pollution, Noise Pollution, Willingness to Pay, Health Status, Pseudo-Panel Data.

1 This research has been funded by the Scientific and Technological Research Council of Turkey (TUBITAK) Scientist Support Directorate (BIDEB) under the Postdoctoral Research Grants Funding Scheme 2219. The authors would like to thank the anonymous reviewers for their valuable comments, suggestions and constructive comments that greatly contributed to the improvement of the quality of this paper. Any remaining errors or omissions remain the responsibility of the authors. This work was based on data from the Income and Living Conditions Survey (ILCS) cross-sectional during period 2006-2012 provided by the Turkish Statistical Institute (TURKSTAT). The data are the copyright of TURKSTAT. The use of the data in this work does not imply the endorsement of TURKSTAT in relation to the interpretation or analysis of the data.

2 Bu araştırma makalesi Türkiye Bilimsel ve Teknolojik Araştırma Kurumu (TÜBİTAK), Bilim İnsanı Destekleme Daire Başkanlığı (BIDDEB) tarafindan yürütülen 2219 Yurtdlşı Doktora Sonrası Araştırma Burs Programı kapsaminda finanse edilmiştir. Tavsiyeleri, değerli ve yapıcı yorumlar ile makale kalitesinin artmasında önemli katkllar sunan isimsiz hakemlere teşekkürü bir borç biliriz. Makaledeki tüm hata ve eksiklikler biz yazarlara aittir.Makale kapsamındaki tüm analizler Türkiye İstatistik Kurumu (TÜiK) tarafindan sağlanan "2006-2012 Gelir ve Yaşam Koşulları Yatay Veriseti" kullanilarak yapılmış olup, verisetinin telif hakkı TÜIK'e aittir. Makale kapsamında uygulanan analizler ve analizler üzerine yapılan yorumlar ise sadece yazarların sorumluluğunda olup TÜIK'e sorumluluk yüklemez. 


\section{JEL Classification Codes : $\quad$ I31, Q51, Q5.}

\section{$\ddot{O} \mathbf{z}$}

Çalışma 2006-2012 yıllarını kapsayan dönem için Türkiye'de sağlı durumunun belirleyicileri ile hava ve gürültü kirliliğindeki azalma için bireylerin ödeme gönüllülüğünü analiz etmektedir. Analizlerde yaş ve bölge kohortları temelinde oluşturulan pseudo (sözde) panel verisetleri kullanılmıştır. Tahminlerde iki ve üç aşamalı en küçük kareler yöntemi kullanılarak araç değişkenleri yaklaşımı izlenmiş olup, rüzgar yönü ile bölgeler bazında kirlilik şikayet oranları araç değişkenleri olarak kullanılmıştır. Sonuçlar genel anlamda hava ve gürültü kirliliğinden şikayet eden bireylerin bunlara yönelik yapılacak iyileştirmeler için ödemeye gönüllü oldukları ve aylık 20-25 TL ödeme yapabileceklerini ortaya koymuştur.

\section{Anahtar Sözcükler $\quad$ : $\quad$ Hava Kirliliği, Gürültü Kirliliği, Gönül Rızasıyla Ödeme, Sağlik Durumu, Pseudo (Sözde) Panel Veri.}

\section{Introduction}

The impact of noise and air pollution on the environment, health and life quality of human beings has become a major topic in scientific research (Currie \& Neidell, 2005). Noise pollution, which is increasing rapidly, is defined as an undesirable sound resulting from both natural sources and man's activities. The increasing noise from traffic, airport and other sources has become a part of the modern life (Okuguchi et al., 2002; Griefahn, 2002). In the last century, and especially in the last 50 years, a huge movement of population to large urban cities took place. This phenomenon disordered the urban planning development and led to huge increase of traffic volume. Production of high noise pollution levels and creation of other environmental problems, including air pollution are some of the consequences of this incidence. In this study we aim to examine the effects of self-reported air and noise pollution on health status and chronic illnesses. The analysis relies on detailed micro-level data derived from the cross-sectional Income and Living Conditions Survey (ILCS) in Turkey over the period 2006-2012. Next, we estimate the marginal willingness to pay (MWTP) for an improvement in health status through the air and noise pollution reduction.

The approach applied in the study is similar to the Life Satisfaction Approach (LSA). One advantage of the LSA is that it does not rely on asking people how they value the environment and it does not require that the housing market should be in equilibrium. Thus, LSA does not require awareness of causal relationships, but rather essentially assumes that pollution prompts changes in well-being and health status and these changes can be driven by observed or unobserved pollution variation (Frey et al., 2010). Even though LSA is feasible in this study, is not precise, because the geographical area used in the analysis is the Nomenclature of Territorial Units for Statistics (NUTS) 1 level. More specifically, in order to map and assign the air pollution data on individuals is possible using the NUTS 1, but the estimates will be much less precise, compared to the analysis that is based on higher disaggregated level of geographical reference, such as city, neighbourhood or post code level. Nevertheless, this study serves as a proposal for future survey designs in Turkey and 
other countries, considering high detailed geographical information for applications that will allow for more accurate estimates. These assessments will provide valuable insights to the policy makers and help them to take up measures and apply regulations related to air quality improvement. To limit the endogeneity issue, we limit the population of interest to nonmovers, since the decision to move may well be correlated to pollution and noise levels. Furthermore, we apply the instrumental variables (IV) approach using two and three stage least squares methods.

The structure of the paper is the following: In section 2 we present a short literature review. Then in section 3 we describe the theoretical and econometric framework followed in the analysis. We present the data and the research sample design in section 4 . In section 5 we report the empirical results, while in section 6 we discuss the main concluding remarks.

\section{Literature Review}

In this section, we present earlier studies about the effects of air and noise pollution on health. Dockery et al. (1993) showed strong relationship between cardiopulmonary diseases and several air pollutants, especially the fine particulate matter $\mathrm{PM}_{2.5}$. Since then, numerous epidemiological studies explored the association between air pollution and health. The investigation in these studies ranges from variations in physiological functions and clinical symptoms, such as heart rate variability, asthma, stroke, lung cancer, premature births and deaths (Delfino et al., 1998; Naeher et al., 1999; Laden et al., 2000; Janssen et al., 2002; O'Neill et al., 2004). Earlier studies explored the relationship between life satisfaction and air pollution and estimated the MWTP for an improvement in air quality using the LSA. Welsch (2002) used cross section data from 54 countries in 1990 and 1995, relating happiness with Nitrogran Dioxides $\left(\mathrm{NO}_{2}\right)$ and he found MWTP equal at $\$ 126$ for a one $\mu \mathrm{g} / \mathrm{m}^{3}$ decrease in $\mathrm{NO}_{2}$. In another study Welsch (2006) used the Eurobarometer, a series of crosssection during the period 1990-1997 for 10 European countries and he explored the impact of Lead $(\mathrm{Pb})$ and $\mathrm{NO}_{2}$ life satisfaction. In this case, the dependent variable is the countryyear average of life satisfaction. Welsch (2006) found a MWTP equal to \$184 for a one milligram per cubic meter $\left(\mu \mathrm{g} / \mathrm{m}^{3}\right)$ decrease in $\mathrm{Pb}$ and $\$ 519$ for $\mathrm{NO}_{2}$. Di Tella and MacCulloch (2007) valued the MWTP at $\$ 171$ for sulphur oxides $\left(\mathrm{SO}_{\mathrm{X}}\right)$ in the OECD countries. Nevertheless, in this study we explore the association between health and pollution. International studies confirm the negative effects of air pollution on mortality and low birth weight. For instance, the study by World Health Organization, (2014) found that the relative risk for a $10 \mu \mathrm{g} / \mathrm{m}^{3}$ increase in exposure to $\mathrm{PM}_{2.5}$. is 1.066 for non-accidental mortality. The relative risks for the same increase in $\mathrm{PM}_{2.5}$ in lung cancer incidence and low birth weight are respectively 1.09 and 1.392 Pedersen et al., 2013; Hamra et al., 2014).

The health risks related to traffic related air and noise pollution, e.g. increased risks of heart attacks, reduction in life expectancy, sleep disturbance, hypertension, cardiovascular risks, poorer school performance and noise annoyance among others, have been extensively explored and documented (Brunekreef \& Holgate, 2002; Hoek et al., 2002; World Health Organization, 2013 ; Basner et al., 2014). Istamto et al. (2014) conducted a survey of 10,000 people in United Kingdom, Germany, Finland, Netherlands and Spain. They found that the 
WTP estimates to avoid road-traffic air pollution effects were $€ 130$ per person per year (pp/y) for general health risks, $€ 330 \mathrm{pp} / \mathrm{y}$ for a $50 \%$ decrease in road-traffic air pollution and $€ 80 \mathrm{pp} / \mathrm{y}$ for a half year longer in life expectancy.

Previous studies have been carried out to explore the effects of noise pollution and they have recognized it as a serious public health issue, especially in the major cities of Turkey (Yilmaz \& Ozer, 2005; Doygun et al., 2008; Ozyonar \& Peker, 2008; Erdogan \& Yazgan, 2009; Ozer et al., 2009; Sisman \& Unver, 2011). However, these studies evaluated the noise pollution and have not estimated the willingness to pay for its reduction. One of the few research applications in Turkey is the study by Tanrıvermiş (1998) who examined the Willingness to Pay (WTP) in Cankaya district of Ankara. The author argues that the specific district considered, because it represents the socio-economic characteristics of Ankara province. The author conducted a survey collecting data from 8,564 households and 2,220 industrial firms and he related Willingness to Pay (WTP) questions to preferences of consumer and producers on environmental taxes. Tanrıvermiş (1998) found that none of these groups is willing to pay for additional taxes or charges that aim to improve the environmental quality. Even though both groups would pay as much as twice than the current charges, the reason of their hesitation lies on the inefficient usage of the government's revenues. In another study, Tekeşin and Shihomi (2014) examined the WTP for mortality risk reduction from lung cancer, traffic accidents and respiratory diseases. The authors found that the value of statistical life (VSL) for lung cancer is 0.56 million US dollars (USD) expressed in Purchasing Power Parity (PPP) and adjusted on year 2012. The respective values for traffic accidents and respiratory diseases are 0.46 and 0.49 USD million.

\section{Methodology}

\subsection{Theoretical Framework}

One of the first theoretical models that explored the effects of air pollution on health was proposed by Gerking and Stanley (1986). The utility function is:

$$
U=U(X, L, H)
$$

, where $X$ is a bundle of consumption goods, $L$ is leisure and $H$ is the Health status. Health is produced by the individual via the following health production function:

$$
H=H(M, E, A)
$$

The inputs to health production include a vector of medical treatment -care $M$, and the vector $E$ that consists of environmental factors, which is the air and noise pollution in our case. Vector $A$ denotes the averting behaviour, and it is expressed by the residential mobility and the moving status of the respondent. From (2) is derived that $H\left(H_{M}>0, H_{E}<0\right.$ and $H_{A}>0$ ). We observe that the term $H_{E}$ is negative, because air and noise pollution have negative effects on health. In this study we explore both general health status and the respondent's chronic illness condition. For this reason the health production function (2) becomes: 


$$
H=H(M(I), I(E, A))
$$

Relation (3) shows that medical care $M$ depends on diseases $I$, while pollution and avoidance behaviour determine those diseases. The person also faces a budget constraint:

$$
w(H)[T-L]+N=P_{x} X+P_{M} M
$$

, where $w$ is the wage, $N$ is the non-labour income, $T$ is the total time endowment, $P_{X}$ and $P_{M}$ denote the prices for $X$ and $M$ respectively. The individual maximizes a utility function subject to a health production function and a full-budget constraint. Merging these two constraints, it can be obtained one full-budget constraint. Considering this final and single constraint, it can be seen that the cost of health production consists of the monetary value of health care inputs and the opportunity cost of the time used for producing health. Wage is a function of health and labour productivity and it is increased with health at a decreasing rate. The Lagrangian function is as follows:

$$
\max V=U[H(M, E, A), X, L]+\lambda\left[w(H)[T-L]+N-P_{x} X-P_{M} M\right]
$$

The first order conditions are:

$$
\begin{aligned}
& \frac{\partial V}{\partial X}=\partial U / \partial X-\lambda P_{X}=0 \\
& \frac{\partial V}{\partial L}=\partial U / \partial L-\lambda w=0 \\
& \partial V / \partial A=\partial U / \partial H((\partial H / \partial M)(\partial M / \partial I)(\partial I / \partial A)+(\partial H / \partial I)(\partial I / \partial A)) \\
& -\lambda\left(P_{A}+\partial w / \partial H((\partial H / \partial M)(\partial M / \partial I)(\partial I / \partial A)+(\partial H / \partial I)(\partial I / \partial A))[T-L]\right) \\
& \partial V / \partial M=(\partial U / \partial H)(\partial H / \partial M)-\lambda\left[P_{M}+(\partial U / \partial H)(\partial H / \partial M)[T-L]\right]
\end{aligned}
$$

Equations (6a)-(6b) show the trade-off between leisure and labour. Taking the total derivative of (3) it will be:

$$
\frac{d H}{d E}=\left(\frac{\partial H}{\partial M} \frac{\partial M}{\partial I}+\frac{\partial H}{\partial I}\right)\left(\frac{\partial I}{\partial E}+\frac{\partial I}{\partial A} \frac{\partial A}{\partial E}\right)
$$

Relation (7) shows that pollution depends on two components. The expression in the first parenthesis shows how health diseases are translated into poor health status. The first term $(\partial H / \partial M)(\partial M / \partial I)$ shows the negative effects of pollution on health and the medical care treatment required. The second term $(\partial H / \partial I)$ shows that health diseases are caused by 
pollution, which are untreated or the individuals ignore treatment. The expression in the second parenthesis shows the relationship between air pollution and health status or illness. By breaking down the whole expression, the first term $(\partial I / \partial E)$ indicates the effects of air pollution on health diseases, while the second term $(\partial I / \partial A)(\partial A / \partial E)$ shows the role of the avoidance behaviour to poor health or illness by limiting contact with noise and air pollution. We attempt to capture this behaviour by considering the movers and non-movers samples. This basic model can serve as a guide for policy makers.

\subsection{Econometric Framework}

\subsubsection{Ordered Probit Cross-Sectional Data}

The first part of this section describes the methodology applied for the health status. The following model for individual $i$, in region $j$ at time $t$ is estimated:

$$
H S_{i, j, t}=\beta_{0}+\beta_{1} e_{j, t}+\beta_{2} \log \left(y_{i, t}\right)+\beta^{\prime} z_{i, j, t}+l_{j}+\theta_{t}+l_{j} T+\varepsilon_{i, j, t}
$$

$H S_{i, j, t}$ is the health status. $e_{j, t}$ is the self-reported environmental variable. More specifically, we examine two self-reported variables. The first variable is noise pollution coming from car traffic, trains, airplanes, factories, neighbourhoods, bar-restaurants and discos. The second is the self-reported air pollution variable which includes fine dust, ozone, grime and fume. The self-reported answers are binary and are coded into the possible answers yes and no. Variable $\log \left(y_{i, t}\right)$ denotes the logarithm of household income and $z$ is a vector of household and demographic factors, discussed in the next section. Set $l_{j}$ represents the region-fixed effects, $\theta_{t}$ is a time-specific vector of indicators for the year, while $l_{j} T$ is a set of area-specific time trends. Vector $\varepsilon_{i, j, t}$ expresses the error term which we assume to be iid. Standard errors are clustered at the area-specific time trends.

\subsubsection{Pseudo Panel Fixed Effects Models}

In this study we use data from the ILCS of Turkey which is based on repeated crosssectional surveys. Several models, discussed in this section, require the availability of panel data, which can also be identified with repeated cross-sectional data under appropriate conditions. One important limitation of this type of data is that we cannot follow the same individuals across time. Thus, their history over time is absent and this does not allow their inclusion into a fixed effects model. However, repeated cross-sectional data suffer less from typical panel data problems like attrition and non-response.

Earlier studies used repeated cross-sectional data into a pseudo-panel data framework. One approach, suggested by Deaton (1985), is to group individuals who share some common characteristics, such as age and region. Then, the averages within these cohorts are estimated and are treated as a pseudo-panel. Following the procedures by Verbeek (2008) and aggregating all observations to cohort level, the resulting model (9) can be written as: 


$$
\bar{H}_{c, j, t}=\bar{a}_{c t}+\beta_{1} \bar{e}_{c t}+\beta_{2} \log \left(\bar{y}_{c t}\right)+\beta^{\prime} \bar{z}_{c t}+\mu_{c t}+l_{j}+\theta_{t}+l_{j} T+\varepsilon_{c, j, t}
$$

Based on the ILCS design, the cohort consists of respondents who belong in the same age group and the same area-location expressed by NUTS 1, as we provide more details in the data section. The resulting data set is a pseudo-panel or synthetic panel with repeated observations over $T$ periods and $C$ cohorts. Set $\mu_{c t}$ represents the cohort effects, while the remained sets denote region, time and area-specific time trends as we mentioned earlier. The main problem of estimating the beta coefficients in (9) is that $\bar{a}_{c t}$ which depends on $t$, is unobserved, and is likely to be correlated with the other covariates. Therefore, treating $\bar{a}_{c t}$ as part of the random error term is likely to lead to inconsistent estimates. Therefore, we treat $\bar{a}_{c t}$ as a fixed unknown parameter and using fixed effects we assume that we can ignore the variation over time. We should notice that we cannot estimate model (9) in a panel framework using ordered Logit and Probit models, since these methods are available only with random effects. In this case, we apply two econometric methods. The first approach is the adapted Probit OLS proposed by van Praag and Ferrer-i-Carbonell (2004), who suggested the conversion of the ordered- dependent variable into a continuous one. Van Praag and Ferrer-i-Carbonell (2004) have shown that Probit OLS gives very similar estimates to the ordered probit model in several applications. Alternative models include the FCF developed by Ferrer-i-Carbonell and Frijters (2004) and the "Blow-Up and Cluster" (BUC) estimator (Baetschmann et al., 2015). Baetschmann et al., (2015) provide reasons that, in general, FCF estimator is inconsistent, because the way of choosing the cutoff point based on the outcome, produces a form of endogeneity (see Baetschmann et al., 2015 for technical details and working example). Thus, the second method we apply is the BUC model.

Having panel data allows us to identify the model from changes in the pollution level within cohorts rather than between cohorts. In this way, we may reduce the plausible endogeneity bias, because regional unobservable characteristics can be correlated with health and pollution and they can be eliminated in a fixed effect model. To limit the endogeneity issue coming from residential mobility, the population of interest is limited also to non-movers. Non-mover status is to be preferred, since this indicates whether the individual has moved in comparison with its current location over the last 5 years. We assume that the variation of air and noise pollution is exogenous between the interviews, and is driven by differences over the time of the year that the interviews are conducted.

\subsubsection{Two Stage and Three Stages Least Squares}

In this section we describe the two and three stage least squares approaches followed in the analysis. Even though we use fixed effects and we restrict the sample to the nonmovers, in an effort to limit endogeneity, coming from residential mobility or omitted variables bias, there are two main reasons why the IV approach is necessary. First, we believe that there is a possible degree of endogeneity problem due to simultaneity bias and reverse causality between the self-reported pollution complaint and health status. Second, the endogeneity can be an issue because of the subjective rating of self-reporting; thus, 
regional air and noise pollution complaint rates are used as instrumental variables. In addition, we instrument for pollution with wind direction. It is well known that air and noise pollution are correlated with wind direction and the latter may have indirect effects on health status. While the remained weather conditions, such as sunny days, temperature and wind speed, are associated with pollution, individuals are able to observe them even at a local or small area and furthermore there is adequate information about them. Thus, people can move or avoid places with poor weather conditions. On the other hand, wind direction is a regional phenomenon and there is not enough and precise information or observation about it. Since we are interested on the estimation of two pollutants we need to estimate two equations simultaneously and therefore a problem with endogeneity may exist for the reasons mentioned above. In this case we use the three-stage least square (3SLS) which is a combination of seemingly unrelated regression developed by Zellner (1962) and two-stage regression with instrumental variables (Zellner \& Theil, 1962). In a multiple equation system, the independent variables differ across the equations, and the errors may be correlated between the equations. Thus, 3SLS can be more efficient than two-stage least squares (Greene, 2008). In the case where self-reported air and noise pollution are endogenous, ordinary least square regression or seemingly unrelated regressions will produce spurious results, so using the IV approach we may eliminate or reduce this bias. The instrumental variable for the individual subjective ratings on air and noise pollution problems is constructed by taking the average complaint rates on NUT 1 level and we find an evidence of a downward bias. In other words, using self-reported environmental complaints, the marginal willingness to pay for improvement is underestimated.

As we mentioned earlier, we instrument the pollution with wind direction which has different effects on rural and urban areas. In urban areas, ambient sound is produced from human sources, such as road traffic. In rural areas, sound can be generated by stationary farms equipment and may be viewed as a noise aggravation at higher sound levels relative to the surrounding sound background level. Regularly, air temperatures are diminished with expanding height over the ground. However, under temperature inversions, air temperatures expand with increasing height above the ground. This causes sound waves to twist descending off this upper layer of warm air, so stable waves can be heard even at long distances (Aecom, 2011; Ovenden et al. 2011; Fraser \& Eng, 2012).

\section{Data}

For the analysis followed we use data from the cross-sectional Income and Living Conditions survey over the years 2006-2012. The respondents are older than 15 years old and all the settlements have been stratified into 2 levels, urban - rural area. According to the State Planning Organisation, settlements with a population of 20,001 and over are defined as urban, while settlements with a population of 20,000 and less are determined as rural. A two-stage sampling design is applied and entire Turkey is divided into blocks which covers 100 households each. The annual sampling size is 13,414 households. The survey also includes regions, which are coded according to the Nomenclature of Territorial Units for Statistics (NUTS) as NUTS level 1 classification and these are: TR1-Istanbul, TR2-West Marmara, TR3-Aegean, TR4- East Marmara, TR5-West Anatolia, TR6- Mediterranean, 
TR7-Central Anatolia, TR8-West Black Sea, TR9-East Black Sea, TRA-North-east Anatolia, TRB-Central east Anatolia, TRC-Southeast Anatolia (Turkish Statistical Institute, 2013).

According to the earlier literature (Luechinger, 2009; Levinson, 2012; Giovanis \& Ozdamar 2016), we consider the following demographic and household variables: household income 3 , gender, age, household type, job status, industry code of the job occupation, house tenure, marital status, education level, type of the fuel mostly used in the dwelling for heating, piped water system in the dwelling, indoor toilet, house size and NUTS 1 regions. The principal health outcome is a self-assessed health $\mathrm{SAH}$ ) variable defined by a response to the following question: "What is your general health status; very good/good/fair/bad/very bad?". The second dependent variable used is a binary variable answering yes or no about whether the individuals suffer from chronic (long-standing) illness.

In table 1 the summary statistics for four different samples are reported. The average household income is around 21,300 Turkish Liras for the total sample, while the respective average is slightly higher for the movers. The self-reported responses for air and noise pollution complaints are similar among all samples. More specifically, the 25 and 17 per cent reported complains for air and noise pollution respectively, while the 75 and 82 per cent declares no problems. . The statistics show that almost all the households in the sample have available piped water in the dwelling at 96 per cent. The 28 per cent of the sample suffers from a chronic illness. The highest percentage is presented in the non-movers sample at 33 per cent, followed by the movers at 24 per cent. Regarding the self-reported health status almost the 65 per cent of the sample states a very good and good health outcome, the 20.74 reports a fair health status, while the remained 15 per cent declares poor health conditions. The non-movers sample reports a slightly higher proportion of poor health at 13.17 per cent, while the movers for environmental or other reasons, shown in panels $\mathrm{C}$ and $\mathrm{D}$, present slightly higher proportions of good health.

In table 2 we present the correlation matrix between household income, self-reported air and noise pollution problems, the dummy whether an individual suffers from a chronic disease and the self-reported ordered health status variable. The negative correlation between household income and health status indicates that a higher income is associated with better health status, given that the latter is codes as 1 for very good and 5 for very badpoor. Similarly, the association between income and chronic disease is negative. Noise and air pollution are associated positively with poor health status and the probability that an individual will report that (s)he suffers from chronic disease. Chronic disease is positively correlated with poor health status, while income is positively associated with air and noise

3 The analysis was also conducted using individual level income; however this is affected by labour force participation which we do not explicitly model here. 
pollution, probably indicating that individuals with higher income are located in more polluted regions, as the urban areas.

\section{Table: 1}

\section{Summary Statistics}

\begin{tabular}{|c|c|c|c|c|}
\hline Variables & Mean & $\begin{array}{l}\text { Standard } \\
\text { Deviation }\end{array}$ & Minimum & Maximum \\
\hline \multicolumn{5}{|c|}{ Panel A: Total Sample } \\
\hline \multicolumn{5}{|c|}{ Panel A1: Continuous variables } \\
\hline Household income & $21.322,12$ & $19.695,18$ & 95,77 & $642.017,8$ \\
\hline \multicolumn{5}{|c|}{ Panel A2: Categorical Variables } \\
\hline Air Pollution Problems (Yes) & 25,06 & Noise Pollution Problems (Yes) & 17,79 & \\
\hline Air Pollution Problems (No) & 74,94 & Noise Pollution Problems (No) & 82,21 & \\
\hline Chronic Diseases (Yes) & 28,32 & Chronic Diseases (No) & 71,68 & \\
\hline Indoor flushing toilet (Yes, for sole use of the household) & 84,32 & Piped water system in the dwelling (Yes) & 96,48 & \\
\hline Indoor flushing toilet (Yes, Shared) & & Piped water system in the dwelling (No) & & \\
\hline Indoor flushing toilet (No) & 11,71 & Health Status (Fair) & 3,52 & \\
\hline Health Status (Very Good) & 3,97 & Health Status (Bad) & 20,74 & \\
\hline Health Status (Good) & 11,88 & Health Status (Vary Bad) & 12,81 & \\
\hline & 52,73 & & 2,04 & \\
\hline \multicolumn{5}{|c|}{ Panel B: Non-Movers Sample } \\
\hline \multicolumn{5}{|c|}{ Panel B1: Continuous variables } \\
\hline Household income & $21,165.37$ & $19,517.76$ & 95.77 & $642,017.8$ \\
\hline \multicolumn{5}{|c|}{ Panel B2: Categorical Variables } \\
\hline Air Pollution Problems (Yes) & 24,83 & Noise Pollution Problems (Yes) & 17,51 & \\
\hline Air Pollution Problems (No) & 75,17 & Noise Pollution Problems (No) & 82,49 & \\
\hline Chronic Diseases (Yes) & 33,05 & Chronic Diseases (No) & 66,95 & \\
\hline Indoor flushing toilet (Yes, for sole use of the household) & 83,75 & Piped water system in the dwelling (Yes) & 96,32 & \\
\hline Indoor flushing toilet (Yes, Shared) & & Piped water system in the dwelling (No) & & \\
\hline Indoor flushing toilet (No) & 11,82 & Health Status (Fair) & 3,68 & \\
\hline Health Status (Very Good) & 4,44 & Health Status (Bad) & 21,00 & \\
\hline Health Status (Good) & 11,82 & Health Status (Vary Bad) & 13,17 & \\
\hline & 51,90 & & 2,11 & \\
\hline \multicolumn{5}{|c|}{ Panel C: Movers (For Environmental Reasons) Sample } \\
\hline \multicolumn{5}{|c|}{ Panel C1: Continuous variables } \\
\hline Household income & $21.661,24$ & $17.705,57$ & $1.581,401$ & $161.110,1$ \\
\hline \multicolumn{5}{|c|}{ Panel C2: Categorical Variables } \\
\hline Air Pollution Problems (Yes) & 28,81 & Noise Pollution Problems (Yes) & 19,25 & \\
\hline Air Pollution Problems (No) & 71,19 & Noise Pollution Problems (No) & 80,75 & \\
\hline Chronic Diseases (Yes) & 24,19 & Chronic Diseases (No) & 75,81 & \\
\hline Indoor flushing toilet (Yes, for sole use of the household) & 85,98 & Piped water system in the dwelling (Yes) & 96,43 & \\
\hline Indoor flushing toilet (Yes, Shared) & & Piped water system in the dwelling (No) & & \\
\hline Indoor flushing toilet (No) & 12,30 & Health Status (Fair) & 3,57 & \\
\hline Health Status (Very Good) & 1,72 & Health Status (Bad) & 20,97 & \\
\hline Health Status (Good) & 12,62 & Health Status (Vary Bad) & 11,22 & \\
\hline & 53,73 & & 1,47 & \\
\hline \multicolumn{5}{|c|}{ Panel D: Movers (For Other Reasons) Sample } \\
\hline \multicolumn{5}{|c|}{ Panel D1: Continuous variables } \\
\hline Household income & $21.820,58$ & $20.301,42$ & 134,005 & $546.629,1$ \\
\hline \multicolumn{5}{|c|}{ Panel D2: Categorical Variables } \\
\hline Air Pollution Problems (Yes) & 25,71 & Noise Pollution Problems (Yes) & 18,66 & \\
\hline Air Pollution Problems (No) & 74,29 & Noise Pollution Problems (No) & 81,34 & \\
\hline Chronic Diseases (Yes) & 24,20 & Chronic Diseases (No) & 75,80 & \\
\hline Indoor flushing toilet (Yes, for sole use of the household) & 86,14 & Piped water system in the dwelling (Yes) & 97,00 & \\
\hline Indoor flushing toilet (Yes, Shared) & & Piped water system in the dwelling (No) & & \\
\hline Indoor flushing toilet (No) & 11,34 & Health Status (Fair) & 3,00 & \\
\hline Health Status (Very Good) & 2,52 & Health Status (Bad) & 19,87 & \\
\hline Health Status (Good) & 12,07 & Health Status (Vary Bad) & 11,68 & \\
\hline & 54,53 & & 1,85 & \\
\hline
\end{tabular}


Table: 2

\section{Correlation Matrix}

Chronic Illness

Health Status

$0,6514 * * * *$

$(0,000)$

$-0,1427 * * * *$

$0,0108 * * *$

$(0,000)$

$0,0083^{* * * *}$

$(0,0003)$

*** indicates significance at $1 \%$ level.
Air Pollution

Noise Pollution

In figure 1 we portray the average health status levels, measured on a scale from 1 (very good) to 5 (very bad) across the three above-mentioned samples over rural and urban areas. More specifically, we present the complaint rates by three samples; non-movers, movers for environmental reasons and movers for other reasons. We observe that individuals located in urban areas report better health outcomes. In figure 2 we show the percentage of the individuals that suffer from chronic and long term diseases and illnesses. Similarly, to figure 1, individuals in rural areas are more likely to suffer from chronic illnesses. This is also explained by the fact that people located in rural areas are older. The average age in rural areas is 45 and in urban areas is 37 . Also the 7 per cent in rural areas is widowed, while the respective percentage in urban areas is 4.5 . This reflects the negative impact of age and widowhood on chronic diseases and health status. Furthermore, more educated and wealthier households are located in urban areas that allow them to have more access to better quality of medical care and health care services. Figures 3-4 illustrate the proportions of individuals that reported complaints about air and noise pollution by region and moving status. The graphs confirm the summary statistics of table 1, where individuals who have moved for environmental reasons and are located in urban areas report higher complaint rates about pollution. This also shows, the persistence of the environmental problems in urban areas, such as the air and noise pollution coming from traffic, population density and others. In figure 5 we depict the average household income. A first concluding remark is that wealthier households are located in urban areas supporting the correlation matrix in table 2 and the results discussed in the next section. The conclusion is that richer, more educated and younger people located in urban areas report higher levels of health outcomes, even though are more likely to state issues about environmental degradation at higher proportions. 
Figure: 1

Health Status

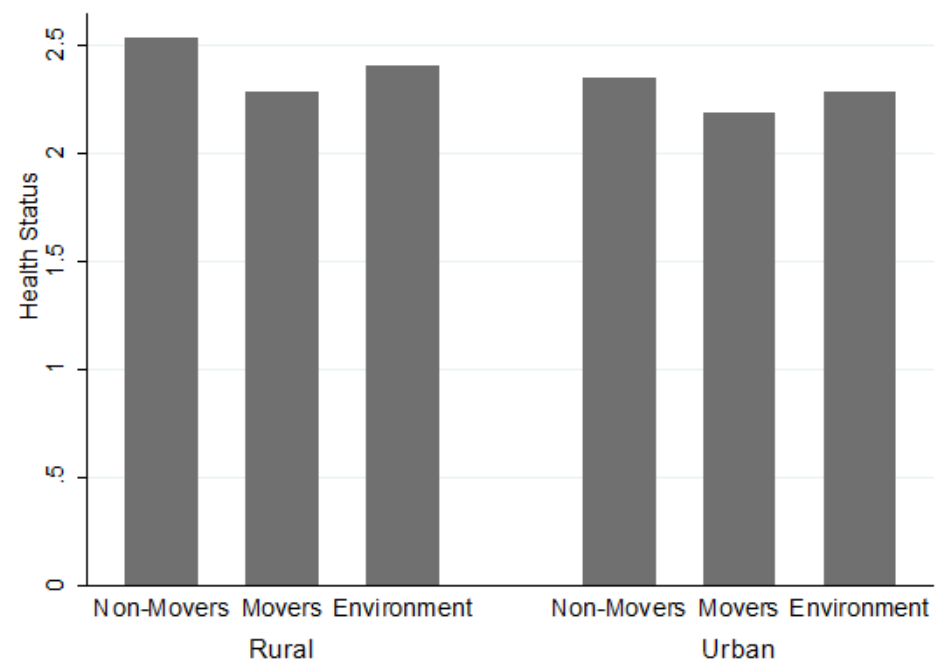

Figure: 2

Chronic Illness

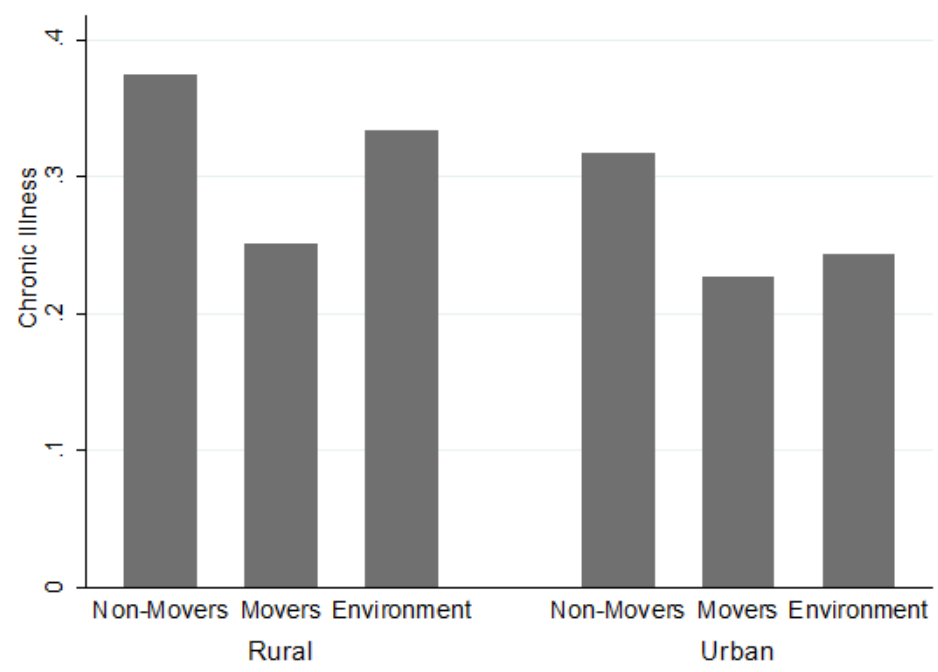


Figure: 3

Air Pollution Complaints

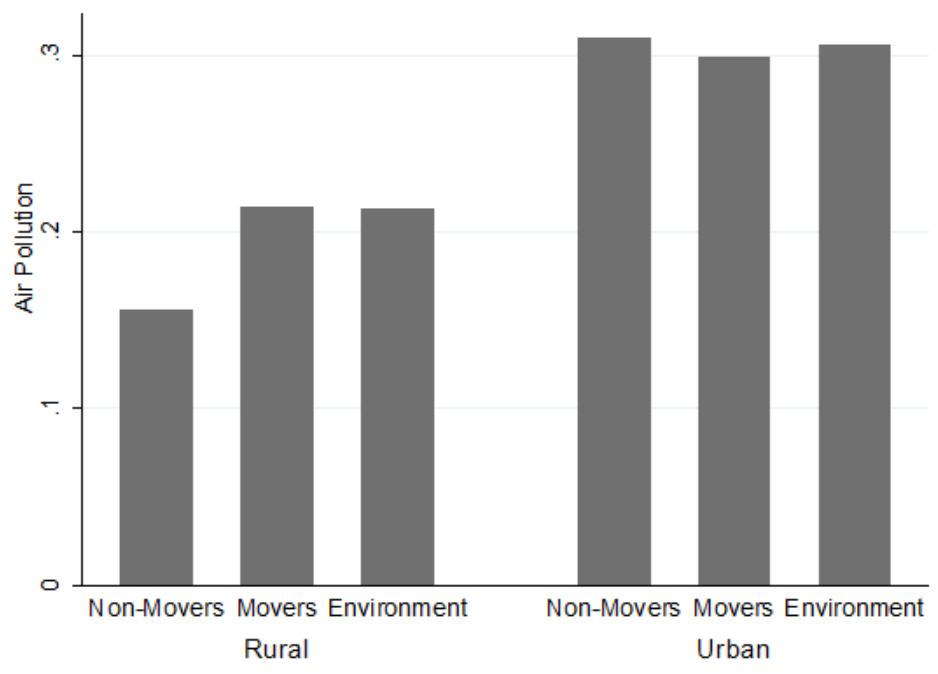

Figure: 4

Noise Pollution Complaints

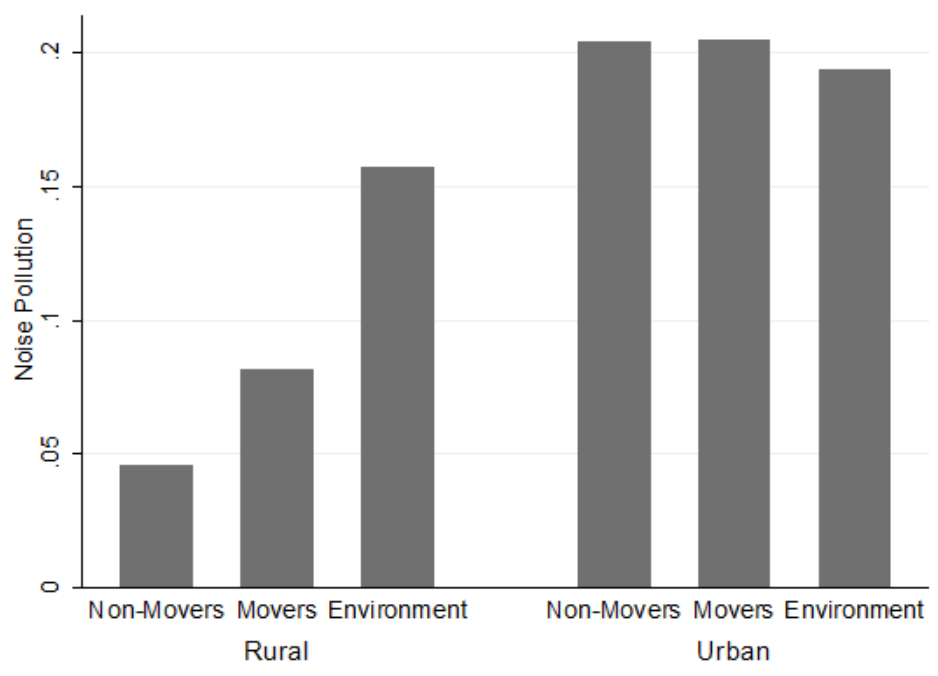


Figure: 5

\section{Household Income}

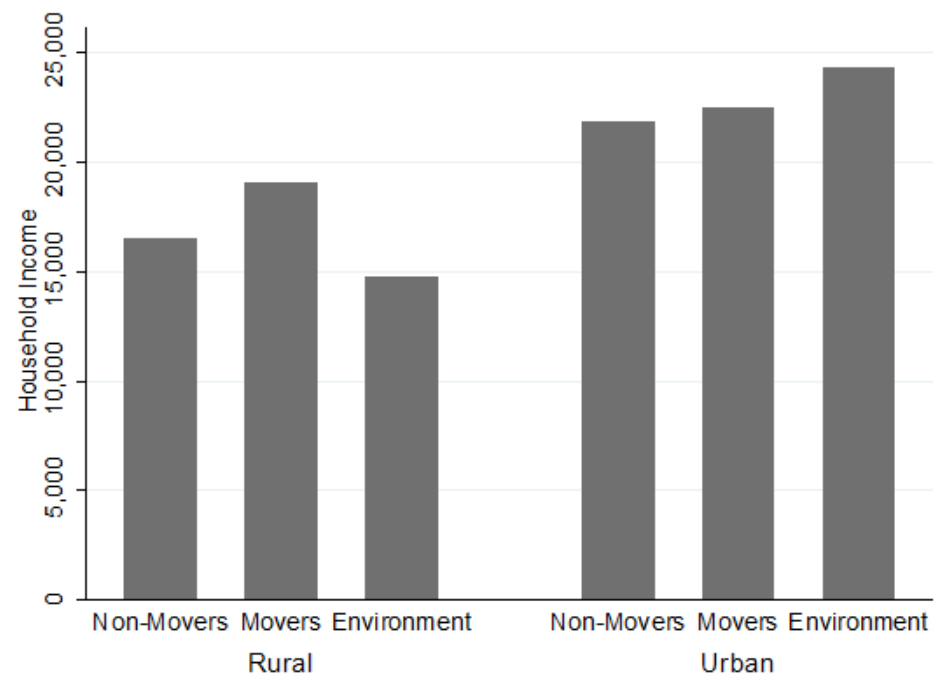

\section{Empirical Results}

In this section we discuss the empirical findings of the study. Equation (9) is estimated separately for each pollutant to disentangle their effects. We additionally estimated the model using pooled adapted Probit-OLS results and Instrumental ordered Probit pooled models. However, for reasons of space limits we do not present the outcomes. Nevertheless, our favoured estimates are those discussed below. In table 3 we show the fixed effects adapted Probit-OLS estimates. We should notice that a negative sign is associated with a better health outcome level, because the self-reported health status variable is defined as 1 for very good health and 5 for very bad health status. The self-reported air and noise complaint coefficients provide positive and significant signs. Therefore, a rise in pollution increases the probability of bad health status. In table 3 the estimates are provided for fours samples; the total sample; the non-movers sample; the movers for environmental reasons movers and the movers for other reasons.

Age has a negative impact on health status as it was expected. This implies that a higher occurrence of health problems is more likely to happen in old age, indicating that health status becomes more important with age. However, it does not indicate that the decrease in health with age is experienced at the same rate by persons which implies that it is heterogeneous among people. Thus, not all the individuals would like to pay the similar amount for the improvement of health status. Income has a negative sign indicating that the higher income is associated with better levels of health outcomes. Wealthier people usually are better educated than poorer and higher income can provide better conditions of housing, 
schooling, and nutrition (Deaton, 2001; 2002). The role of education in health status is a key determinant of well-being and living standards. Moreover, in adult life the individuals' living standards and health are determined also by their life-course experience, partly determined by the social roles and class - in terms of marital status, employment, parenthood status - and less by other household characteristics as fuel type used, pipe water infrastructure. The respondents who are widowed report the lowest levels of health status followed by singles, separated and divorced. Regarding the education level, it becomes clear that higher education levels are related with improvement on health outcomes. Similarly, job status is a critical determinant of health status. The reference category is the full-time employees. Thus, a positive sign for the part-time employees, unemployed and retired individuals indicates a lower level of health status relative to the full employed respondents. Especially, the retired and widowed people report the lowest levels of health status, reflecting their old age which implies additional health problems. More specifically, more than 40 per cent of the widowed individuals are older than 55 years old. Moreover, full-time employment provides larger earning potentials and additional wealth, than part-time employment and unemployment. In table 3 the results for occupation codes are reported. We observe that there is no difference on health status between individuals who are professionals and the reference category which is the managers' class. Skilled workers employed in agricultural and forestry industry present lower levels of health outcomes followed by clerical support workers. Regarding the household type the results are mixed. Another factor that we could have used is the household size or the number of children. However, the household type allows us to examine in more details the effects and the structure of a household, rather than considering only its size. More specifically, from table 3 it is obvious that a couple, younger than 65 years old with no dependent children or a household composed of two adults with one or two dependent children are healthier than a household that consists of a single person. These findings are also captured by the marital status. On the other hand, a household, which consists of two adults with no dependent children, but at least one of them is older than 65 years old, are less healthy than single persons, which reflects their old age, as we saw earlier in the case of widowed and retired people. The related literature emphasizes that family support and the household size can be protective and beneficial to people with a chronic illness (Aldwin \& Greenberger, 1987; Doornbos, 2001). Therefore, household type and support is a proxy for home health care and it may serve as a substitute for medical care obtained in the market.

Overall, the results show that education is perhaps the most important socioeconomic status (SES) component. This can be explained by the fact that education determines and shapes future labour market opportunities and earning potentials. Moreover, education provides knowledge and life skills that allow individuals to gain access to information and resources to health services and care of better quality. The general findings so far are consistent with earlier studies (Benzeval et al. 2000; Deaton, 2001; 2002; Beckett \& Elliott 2002; Bostean, 2010).

Additional determinants we examine include the indoor flushing toilet and piped water in the dwelling and the type of fuel used for heating. In table 3 we observe that respondents who reside in dwellings not having indoor flushing toilet or piped water supply 
report lower health levels. Regarding the type of fuel used for heating in the dwelling, households that use natural gas, fuel-oil and electricity report better health outcomes relative to households whose main type of fuel is dried cow dung, coal or wood. Additionally, we observe that in both urban and rural areas the air and noise pollution have significant impact on health. Although rural areas are generally quiet, due to the development of technology modern farms mostly use noisy equipment and vehicles that cause air pollution (Aecom, 2011; Ovenden et al. 2011). Also, another major source of noise is traffic which is produced mainly from freeways. As noise depends on wind speed and wind direction, one action that can be implemented, to reduce noise exposure, is the construction of a noise barrier next to the freeways 4 .

Next we present the MWTP estimates. Respondents who complain about air pollution are willing to pay more for an improvement in air quality by 19.67 TL per month considering the total sample, $18.58 \mathrm{TL}$ for the non-movers sample, 32.54 TL for the movers for environmental reasons movers and $22.82 \mathrm{TL}$ concerning the movers for other reasons. The respective values for the noise pollution reduction are: $21.29,21.38,29.54$ and $20.77 \mathrm{TL}$ based on columns (5)-(8) of Table 3. Therefore, individuals who moved because of environmental or other reasons evaluate the air pollution more than noise, while the MWTP values for the non-movers are similar with those derived using the total sample. This can be explained by the fact that 76 per cent of the survey consists of non-movers.

4 We also explored the effects of wind speed and humidity on health status and are negative, while average temperature has positive impact on health. There are various explanations for that, such as humidity and rain have negative impact on health status which comes from the chemical compounds and air pollutants contained in humidity and others. However, we do not present the results for space reasons. 


\section{Table: 3}

Model
Household Income
Air Pollution
Noise Pollution
Age
Marital Status (Reference Married)
Marital Status (Single never married)
Marital Status (Widowed)
Marital Status (Divorced)
Marital Status (Separated)
Education Level (Reference Illiterate)
Primary school
High school
Higher education level
Job Status (Reference Empl, Full Time)
Job Status (Employee Part Time)
Job Status (Self-Employed Part Time)
Unemployed
Retired
Occupation code (Clerical Support Workers)
Occupation code (Skilled agricultural, forestry)
Ocode (Professionals)
Ochation code

\begin{tabular}{|c|c|c|}
\hline & & \\
\hline (1) & (2) & (3) \\
\hline$-0,1292^{* * * *}$ & $-0,1330^{* * * *}$ & $-0,0891 *$ \\
\hline$(0,0065)$ & $(0,0075)$ & $(0,0463)$ \\
\hline $0,1166^{* * * *}$ & $0,1142 * * *$ & $0,1455^{* *}$ \\
\hline$(0,0076)$ & $(0,0089)$ & $(0,0689)$ \\
\hline $\begin{array}{c}0,0200^{* * * *} \\
(0,0004)\end{array}$ & $\begin{array}{c}0,0204 * * * \\
(0,0004)\end{array}$ & $\begin{array}{c}0,0165 * * * \\
(0,0055)\end{array}$ \\
\hline, $0293 * *(0,0134)$ & $\begin{array}{c}0,0176 \\
(0,0158)\end{array}$ & $\begin{array}{c}0,0505 \\
(0,2301)\end{array}$ \\
\hline $0,2366 * * *$ & $0,2299 * * *$ & 0,0290 \\
\hline$(0,0320)$ & $(0,0363)$ & $(0,3310)$ \\
\hline $0,1813 * * *$ & $0,1769^{* * * *}$ & $0,0577(0,2949)$ \\
\hline $0,1324 * * *$ & $0,1479 * * *$ & 0,3327 \\
\hline$(0,0471)$ & $(0,0552)$ & $(0,5351)$ \\
\hline $\begin{array}{c}-0,2637 * * * \\
(0,0161)\end{array}$ & $\begin{array}{c}-0,2631 * * * * \\
(0,0183)\end{array}$ & $\begin{array}{c}-0,3193^{*} \\
(0,1781)\end{array}$ \\
\hline$-0,3711$ **** & $-0,3708^{* * * *}$ & $-0,4148^{* *}$ \\
\hline$(0,0198)$ & $(0,0227)$ & $(0,1942)$ \\
\hline$-0,4177$ **** & $-0,4126^{* * * *}$ & $-0,5235^{* *}$ \\
\hline$(0,0213)$ & $(0,0246)$ & $(0,2337)$ \\
\hline $0,1429 * * *$ & $0,1562 * * *$ & 0,1849 \\
\hline$(0,0093)$ & $\begin{array}{c}(0,0153) \\
0,072 * * *\end{array}$ & $(0,1439)$ \\
\hline $0,1459 * * *$ & $0,1072 * * *$ & $\begin{array}{c}0,5474 \\
0,5837)\end{array}$ \\
\hline$(0,0133)$ & $(0,0284)$ & $(0,5837)$ \\
\hline $0,1070 * * *$ & $0,1083^{* *}$ & $0,8064 *$ \\
\hline$(0,0256)$ & $(0,0505)$ & $(0,4454)$ \\
\hline $0,9031^{*}$ & $0,9659^{* *}$ & $0,8178^{*}$ \\
\hline$(0,4765)$ & $(0,4837)$ & $(0,4180)$ \\
\hline$-0,0185$ & $-0,0414 * *$ & $\begin{array}{l}-0,0635 \\
-02244\end{array}$ \\
\hline $\begin{array}{l}(0,0165) \\
0,0353 *\end{array}$ & $\begin{array}{c}(0,0196) \\
0,0236\end{array}$ & $\begin{array}{r}(0,2244) \\
-0,0259\end{array}$ \\
\hline $\begin{array}{l}0,0353 * \\
(0,0180)\end{array}$ & $\begin{array}{c}0,0236 \\
(0,0211)\end{array}$ & $\begin{array}{r}-0,0259 \\
(0,1902)\end{array}$ \\
\hline $0,0424 * * *$ & $0,0368 * *$ & 0,0802 \\
\hline$(0,0150)$ & $(0,0173)$ & $(0,1920)$ \\
\hline
\end{tabular}

$(4)$
$-0,1200^{* * *}$
$(0,0134)$
$0,1231^{* * *}$
$(0,0151)$

$0,0191^{* * *}$

$(0,0008)$

$0,0671 * *$

$(0,0260)$

$(0,0698)$

$0,2058^{* * * *}$

$(0,0518)$

$(0,0518)$
0,0996

$(0,0923)$

$-0,2611^{* * * *}$

$(0,0348)$

$-0,3658^{* * * *}$

$(0,0416)$
$-0,4192 * * * *$

$(0,0442)$

$0,1163 * * *$

$(0,0275)$

$0,1221^{* * * *}$

$(0,0196)$
$0,2211 *$

$(0,1171)$

$-0,5952 * * * *$

$(0,2236)$

0,0435
$(0,0316)$

$0,0316)$
0,0289

0,0289
$(0,0349)$

$(0,0349)$
$0,0580^{*}$

$0,0580^{*}$
$(0,0306)$
(5)

$-0,1277^{* * * *}$
$(0,0065)$

$0,1248 * * *$

$(0,087)$

(6)

$-0,1317^{* * *}$

$(0,0075)$

$0,1300 * * *$

$(0,0102)$

$0,0205^{* * * *}$

$(0,0005)$

0,0153

$0,0275^{* * *}(0,0135)$

0,2340 ***

$(0,0321)$

0,1795 ***

$(0,0270)$

$0,1284 * 0471)$
0,0

$-0,2646^{* * * *}$

$(0,0161)$

$-0,3719^{* * *}$

$(0,0198)$

$-0,4160^{* * *}$
$(0,0213)$

0,1429 ***

(0,0093)

$0,14435^{* * *}$

$(0,0133)$
$0,1048 * *$

$(0,0255)$

$0,9075^{*}$
$(0,4767)$

$-0,0194$

$(0,0165)$

$0,0355^{*}$

$(0,0180)$
$0,0408 * *$

0,0408 *
$(0,0150)$
$(0,0158)$

$0,2264 * * *$

$0,1728^{* * * *}$

$0,1728^{* * * *}$
$(0,0320)$

$0,1441^{* * * *}$

$(0,0551)$

$-0,2638^{* * * *}$

$(0,0183)$

$-0,3725 * * *$

$(0,0227)$

$-0,4118^{* * *}$

$(0,0246)$

(0,0153)

$0,1045^{* * *}$

$(0,0285)$

0,1077 **

$(0,0505)$

0,9621 **

$(0,4935)$

$-0,0429 * *$

$(0,0196)$

0,0242

0,0242

$(0,0211)$

$0,0345^{* *}$
$(0,0173)$
(7)

$-0,0832^{*}$

$(0,0431)$

(8)

$-0,1185 * * *$
$(0,0134)$

$(9)$
$-0,1329 * * *$

$(0,0075)$

$0,1082^{* * *}$

$(0,0093)$

$0,1407 * * \quad 0,1106 * * * \quad 0,1115^{* * * *}$

$(0,0682) \quad(0,0172) \quad(0,0107)$

$\begin{array}{ccc}0,0169^{* * *} & 0,0192 * * * & 0,0204 * * * \\ (0,0055) & (0,0008) & (0,0005)\end{array}$

$0,0722 \quad 0,0672 * * \quad 0,0406$ ***

$(0,2303) \quad(0,0270) \quad(0,0158)$

$0,0281 \quad 0,2630^{* * *} \quad 0,2277^{* * *}$

$\begin{array}{lll}(0,3312) & (0,0701) & (0,0363)\end{array}$

$0,0742(0,2952) \quad 0,2085 * * * \quad 0,1750 * * *$

$\begin{array}{ccc}0,3775 & (0,0517) & (0,0319) \\ & 0,0931 & 0,1435 * * *\end{array}$

$\begin{array}{lll}(0,5286) & (0,0926) \quad(0,0551)\end{array}$

$-0,3178 * \quad-0,2623 * * * \quad-0,2637$ ***

$(0,1729) \quad(0,0348) \quad(0,0183)$

$-0,4183 * \cdots \quad-0,3633 * * * \quad-0,3733 * * *$

$-0,5169 * * \quad-0,4150 * * * \quad-0,4151 * * *$

$(0,2310) \quad(0,0442) \quad(0,0246)$

$0,1737 \quad 0,1179^{* * *} \quad 0,1547^{* * * *}$

$(0,1440)$

0,5234

$(0,5740)$

$0,8252^{*}$

$(0,4743)$

$(0,4182)$

$(0,0277) \quad(0,0153)$

$0,1232 * * * \quad 0,1038 * * *$

$\begin{array}{ll}(0,0197) & (0,0284) \\ 0,2202 * & 0,1089 * *\end{array}$

$(0,1169) \quad(0,0428)$

$-0,5641^{* * *} \quad 0,9451^{*}$

$(0,1846) \quad(0,4883)$

$\begin{array}{lll}-0,0744 & 0,0448 & -0,0435 * *\end{array}$

$(0,216) \quad(0,0316) \quad(0,0195)$

$\begin{array}{lll}-0,0243 & 0,0271 & 0,0217\end{array}$

$\begin{array}{lll}-0,1913) & (0,0349) & (0,0211) \\ 0,0672 & 0,0555 & 0,0412\end{array}$

$\begin{array}{lll}0,0672 & 0,0555^{*} & 0,0412 * *\end{array}$

$\begin{array}{ccc}0,0672 & 0,0555^{*} & 0,0412^{* * *} \\ (0,1916) & (0,0306) & (0,0173)\end{array}$ 
Table: 3 (cont.)
Adapted Probit Fixed Effects

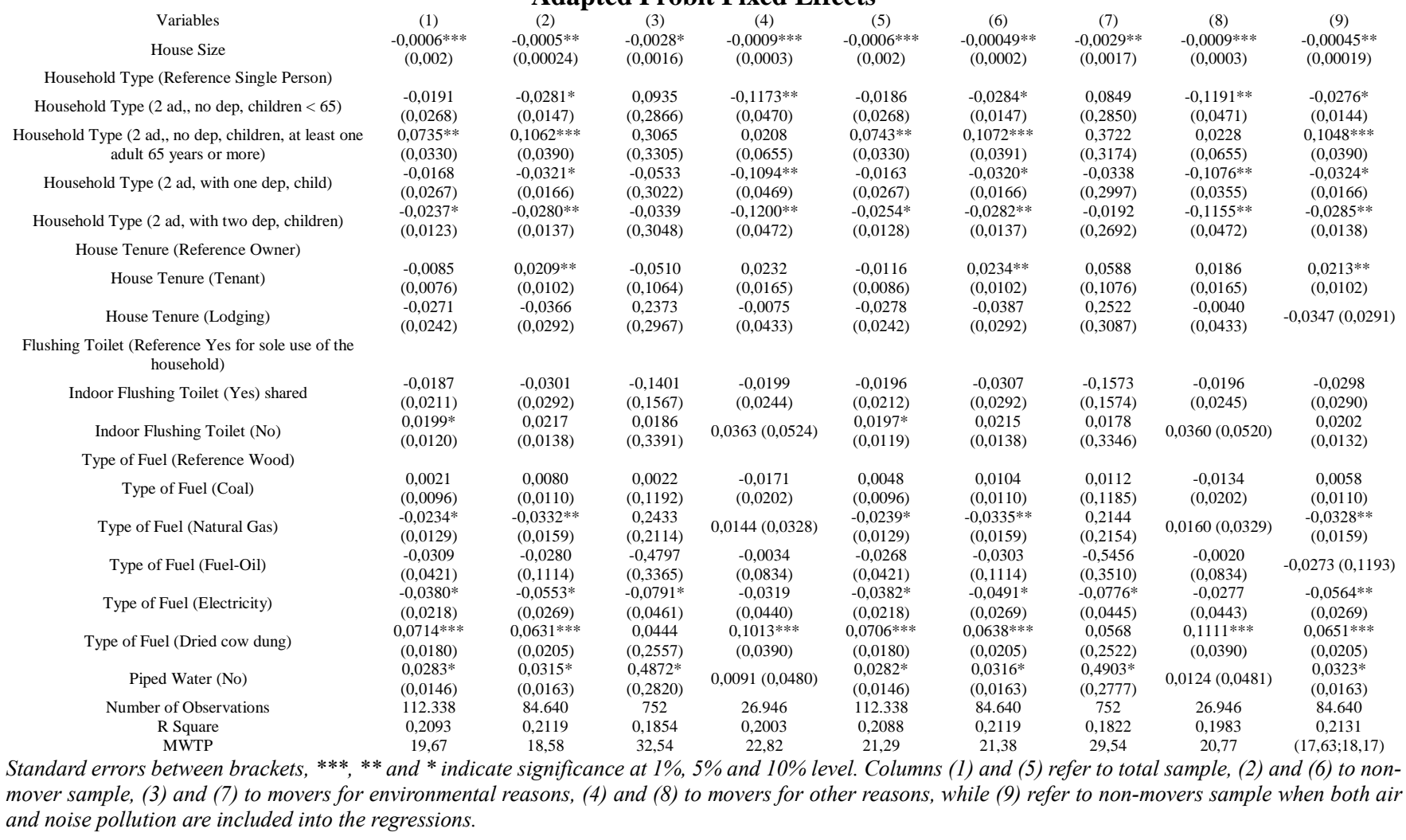

(2) (3) (4) (5)

$\begin{array}{lllr}-0,000024) & (0,0016) & (0,0003) & (0,002\end{array}$

0019)

Household Type (Reference Single Person)

( 2 ad,, no dep, children, at least one

0,0935

$-0,1173^{* * *}$

$-0,0186$

$0,0743^{*}$

$0,0735^{* * *}$

$0,1062 * *$

0,3065

$(0,0330)$

$-0,0321^{*}$

$(0,0267)$

$0,1072^{* * * *}$

$(0,0144)$

$(0,0390)$

$(0,0166)$

$(0,0138)$

House Tenure (Reference Owner)

House Tenure (Tenant)

Tenure (Lodging)

$-0,0085$

0,0209

$0,0234 * *$

$(0,0292)$

$(0,0165)$

$0347(0,0291)$

household)
Indoor Flushing Tolet (Yes) shared

Indoor Flushing Toilet (No)
Type of Fuel (Reference Wood)

Type of Fuel (Coal)

Type of Fuel (Natural Gas)

Type of Fuel (Fuel-Oil)

Type of Fuel (Electricity)

Fuel (Dried cow dung)

$-0,0199$

$-0,0196$

$-0,0307$

$-0,1573$

$-0,0298$

$0360(0,0520)$

0,0021

$-0,023$

(0332*

$-0,0171$

(0,0202)

$(0,0096)$

0,0112

$-0,013$

$(0,0110)$

$-0,0280$

$(0,1114)$

$-0,0553^{*}$

$(0,2114)$

0,2144

0,0631 **

$-0,0564^{* *}$

$0,0315^{*}$

$(0,0440)$

$-0,0382$

$-0,0776 *$

$0,0651 * * *$

$0,0323^{*}$

$(0,2820)$

0,0282 $124(0,0481)$

84.640

112.33

0,1854

0.2088

0,2131

mover sample, (3) and (7) to movers for environmental reasons, (4) and (8) to movers for other reasons, while (9) refer to non-movers sample when both air and noise pollution are included into the regressions. 
Table 4 illustrates two alternative econometric models and the analysis is restricted to the non-movers to limit the endogeneity issue discussed in the earlier sections. We use the panel ordered Logit with random effects model and the BUC method. The results confirm the findings described previously. While coefficients present the same sign, the magnitude is higher because these methods use the Logit approach. In this case the coefficients are almost 4 times higher than those derived from the linear regressions. Nevertheless, the MWTP values in table 4 are very similar with those reported in table 3. In tables 5-6 the results for the two and three stage least squares respectively are illustrated. The sign and the impact of the various determinants on health are similar with the previous results confirming the estimates and the importance of each factor on health. However, the MWTP values in tables 5-6 are higher. More specifically, regarding the two stage least squares (2SLS), the MWTP values for air and noise pollution are 23.00 TL and 27.67 TL per month, while the respective MWTP values found with the adapted Probit model are 17.63 TL and 18.17 TL. One concluding remark is that the estimates of the fixed effects model are biased downwards and therefore the MWTP is underestimated. Similarly, the MWTP values derived from the three stage least squares (3SLS) are higher and equal at 20.13 TL and 24.24 TL per month, when instruments are used. In addition, when we assume that the self-reported pollution complaints are exogenous, MWTP values still remain higher than the values derived from the fixed effects model. More specifically, the respondents are willing to pay more by 19.21 TL and 22.66 TL per month than the individuals who do not have any concern about the pollution. We observe that the MWTP values derived from the 3SLS are slightly lower than those calculated based on the 2SLS. As we discussed in the methodology section, the former approach can be more robust for two reasons. First, disentangling the effects of air and noise pollution by estimating the equations separately may not give precise estimates of the MWTP values. Second, there is a strong possibility that the error term between the two equations, one for each pollution, is correlated, and therefore, the 3SLS method is more appropriate. 
Table: 4

Variables

Household Income

Air Pollution

Noise Pollution

Age

Marital Status (Single never married)

Marital Status (Widowed)

Marital Status (Divorced)

Marital Status (Separated)

Primary school

High school

Higher education level

Job Status (Employee Part Time)

Job Status (Self-Employed Part Time)

Unemployed

Retired

Occupation code (Professionals)

Occupation code (Clerical Support Workers)

Occupation code (Skilled agricultural, forestry and fishery workers)

House Size

\section{Panel Ordered Logit and BUC Estimates for Non-Movers}

\begin{tabular}{|c|c|c|}
\hline Panel Ordered Logit & BUC & Variables \\
\hline $\begin{array}{c}-0,2924 * * * \\
(0,0137)\end{array}$ & $\begin{array}{c}-0,3444 * * * \\
(0,0211)\end{array}$ & Household Type ( 2 ad,, no dep, children \\
\hline $\begin{array}{c}0,2121 * * * \\
(0,0178)\end{array}$ & $\begin{array}{l}0,2360^{* * *} \\
(0,0267)\end{array}$ & Household Type ( 2 ad,, no dep, children, at least \\
\hline $\begin{array}{c}0,2382 * * * \\
(0,0204)\end{array}$ & $\begin{array}{c}0,2960 * * * \\
(0,0302)\end{array}$ & Household Type ( 2 ad, with one dep, ch \\
\hline $\begin{array}{c}0,0549^{* * *} \\
(0,0082)\end{array}$ & $\begin{array}{c}0,0541^{* * *} * \\
(0,0013)\end{array}$ & Household Type ( 2 ad, with two dep, chi \\
\hline $0,1990^{* * * *}(0,0250)$ & $\begin{array}{c}0,1418 * * * \\
(0,0496)\end{array}$ & House Tenure (Tenant) \\
\hline $\begin{array}{c}0,5251^{* * *} \\
(0,0637)\end{array}$ & $\begin{array}{c}0,6434 * * * \\
(0,0991)\end{array}$ & House Tenure (Lodging) \\
\hline $\begin{array}{c}0,5565^{* * *} * \\
(0,0576)\end{array}$ & $\begin{array}{c}0,5017^{* * *} * \\
(0,0884)\end{array}$ & Indoor Flushing Toilet (Yes) shared \\
\hline $\begin{array}{c}0,6039^{* * *} * \\
(0,1033)\end{array}$ & $\begin{array}{c}0,5114 * * * \\
(0,1546)\end{array}$ & Indoor Flushing Toilet (No) \\
\hline $\begin{array}{c}-0,6769 * * * \\
(0,0282)\end{array}$ & $\begin{array}{c}-0,5379 * * * \\
(0,0477)\end{array}$ & Type of Fuel (Coal) \\
\hline $\begin{array}{c}-0,9943 * * * \\
(0,0385)\end{array}$ & $\begin{array}{c}-0,8715 * * * \\
(0,0622)\end{array}$ & Type of Fuel (Natural Gas) \\
\hline $\begin{array}{c}-1,165 * * * \\
(0,0437)\end{array}$ & $\begin{array}{c}-1,042 * * * \\
(0,0688)\end{array}$ & Type of Fuel (Fuel-Oil) \\
\hline $\begin{array}{c}0,3457^{* * *} * \\
(0,0253)\end{array}$ & $\begin{array}{c}0,3540^{* * *} \\
(0,0399)\end{array}$ & Type of Fuel (Electricity) \\
\hline $\begin{array}{c}0,3645 * * * \\
(0,0438)\end{array}$ & $\begin{array}{c}0,2081^{* * *} \\
(0,0751)\end{array}$ & Type of Fuel (Dried cow dung) \\
\hline $\begin{array}{c}0,3694^{*} \\
(0,1884)\end{array}$ & $\begin{array}{l}0,4228 * * \\
(0,2059)\end{array}$ & Piped Water (No) \\
\hline $\begin{array}{c}1,8682 * * * \\
(0,0710)\end{array}$ & $\begin{array}{r}1,210^{*} \\
(0,6164)\end{array}$ & Number of Observations \\
\hline $\begin{array}{l}-0,0368 \\
(0,0428)\end{array}$ & $\begin{array}{c}-0,1130^{*} \\
(0,0606)\end{array}$ & LR Chi Square \\
\hline $\begin{array}{c}0,1259^{* * *} \\
(0,0429)\end{array}$ & $\begin{array}{c}0,0837 \\
(0,0626)\end{array}$ & \\
\hline $\begin{array}{c}0,1518 * * * \\
(0,0338)\end{array}$ & $\begin{array}{l}0,1140 * * \\
(0,0480)\end{array}$ & MWTP \\
\hline$-0,0013 * * *$ & $-0,0013 * *$ & \\
\hline
\end{tabular}

\begin{tabular}{|c|c|}
\hline & \\
\hline Panel Ordered Logit & BUC \\
\hline $\begin{array}{c}-0,1350 * * \\
(0,0673)\end{array}$ & $-0,0417 *(0,0238)$ \\
\hline $0,2194 * * *$ & 0,2041 \\
\hline$(0,0759)$ & $(0,2076)$ \\
\hline$-0,1359 * *$ & $-0,0462 * *$ \\
\hline$(0,0676)$ & $(0,0215)$ \\
\hline$-0,1335^{* *}$ & $-0,0453 * *$ \\
\hline$(0,0673)$ & $(0,0221)$ \\
\hline 0,0242 & 0,0549 ** \\
\hline$(0,0707)$ & $(0,0255)$ \\
\hline $\begin{array}{l}-0,0903 \\
(0,0619)\end{array}$ & $-0,0825(0,0866)$ \\
\hline $\begin{array}{l}-0,0143 \\
(0,0376)\end{array}$ & $\begin{array}{l}-0,0575 \\
(0,0621)\end{array}$ \\
\hline $0,0722 * * *$ & $0,0659^{*}$ \\
\hline$(0,0245)$ & $(0,0375)$ \\
\hline 0,0161 & 0,0400 \\
\hline$(0,0199)$ & $(0,0298)$ \\
\hline $\begin{array}{c}-0,0972 * * \\
(0,0395)\end{array}$ & $-0,0676 * *(0,0357)$ \\
\hline $\begin{array}{l}-0,1365 \\
(0,1032)\end{array}$ & $-0,1606(0,1579)$ \\
\hline $\begin{array}{c}-0,1926 * * * \\
(0,0569)\end{array}$ & $\begin{array}{c}-0,1623 * * \\
(0,0793)\end{array}$ \\
\hline $\begin{array}{c}0,1269 * * * \\
(0,0342)\end{array}$ & $0,1978^{* * *}(0,0545)$ \\
\hline $\begin{array}{l}0,0636^{*} \\
(0,0382)\end{array}$ & $\begin{array}{c}0,1301^{* *} \\
(0,0636)\end{array}$ \\
\hline 84.640 & 82.796 \\
\hline & $\begin{array}{c}6.756,20 \\
{[0,000]}\end{array}$ \\
\hline
\end{tabular}

$(17,30 ; 20,11)$

$(18,21 ; 20,78)$

Standard errors between brackets, p-value between square brackets, ***, ** and * indicate significance at 1\%, 5\% and $10 \%$ level. 
Table: 5

Two Stages Least Squares Estimates for Non-Movers

Variables

Household Income

Air Pollution

Noise Pollution

Age

Marital Status (Single never married)

Marital Status (Widowed)

Marital Status (Divorced)

Marital Status (Separated)

Primary school

High school

Higher education level

Job Status (Employee Part Time)

Job Status (Self-Employed Part Time)

\section{Unemployed}

Retired

Occupation code (Professionals)

Occupation code (Clerical Support Workers)

Occupation code (Skilled agricultural, forestry and fishery workers)

House Size

$$
\begin{gathered}
2 \text { SLS } \\
-0,1291 * * * \\
(0,0080) \\
0,1304 * * \\
(0,0594) \\
0,1569 * * \\
(0,0723) \\
0,0203 * * * \\
(0,0005)
\end{gathered}
$$

$0,0202(0,0189)$

$0,2242 * * * *$

$0,1712 * * *$

$0,1712^{* * * *}$

$0,1257^{*}$

$(0,0647)$

$-0,2673^{* * * *}$

$-0,3949 * * *$

$(0,0242)$

$-0,4340 * *$

$0,1380^{* * * *}$

$(0,0164)$

$0,0869^{* * * *}$

$(0,0302)$

$0,1904 *$

$(0,1064)$

$0,6814 * *$

$(0,3455)$

$-0,0538^{* *}$

$(0,0234)$

$0,0245^{*}$

$(0,0134)$

$0,0850 * * *$

$(0,0251)$

$-0,0003 * * *$
Variables

Household Type ( 2 ad,, no dep, children < 65)

Household Type ( 2 ad,, no dep, children, at least one adult 65 years or more)

Household Type ( 2 ad, with one dep, child)

Household Type (2 ad, with two dep, children)

House Tenure (Tenant)

House Tenure (Lodging)

Indoor Flushing Toilet (Yes) shared

Indoor Flushing Toilet (No)

Type of Fuel (Coal)

Type of Fuel (Natural Gas)

Type of Fuel (Fuel-Oil)

Type of Fuel (Electricity)

Type of Fuel (Dried cow dung)

Piped Water (No)

Number of Observations

$$
\text { R Square }
$$

Sargan statistic exogeneity test

Cragg-Donald Weak identification test Wald F-statistic

MWTP
2SLS

$-0,0971 * *(0,0468)$

$0,0809^{*}$

$(0,0417)$

$-0,0982 * *$

$(0,0447)$

$-0,0927$ **

$(0,0402)$

0,0167
$(0,0152)$

$-0,0032(0,0332)$

$-0,0075$

$(0,0169)$

$0,0138(0,0236)$

$-0,0198(0,0144)$

$-0,0289(0,0275)$

$-0,0887(0,0613)$

$-0,1296 * * *$

$(0,0377)$

$0,1092 * * *(0,0331)$

$0,0484 *(0,0249)$

60.224

0,1501

1,768 [0,1837]

94,136

$23,00 ; 27,67)$

Standard errors between brackets, p-value between square brackets, ***, ** and * indicate significance at 1\%, 5\% and $10 \%$ level. 
Table: 6

\begin{tabular}{ccc}
\multicolumn{2}{c}{ Three Stages Least Squares } & Estimates for Non-Movers \\
Variables & Exogenous & Endogenous \\
Household Income & $-0,1171^{* * *}$ & $-0,1170^{* * * *}$ \\
& $(0,0046)$ & $(0,0046)$ \\
Air Pollution & $0,1181^{* *}$ & $0,1237^{* *}$ \\
& $(0,0538)$ & $(0,0537)$ \\
Noise Pollution & $0,1392^{* *}$ & $0,1489^{* *}$ \\
MWTP & $(0,0674)$ & $(0,0677)$ \\
& $(19,21 ; 22,66)$ & $(20,13 ; 24,24)$
\end{tabular}

Standard errors between brackets, *** and ** indicates significance at $1 \%$ and $5 \%$ level.

Next we present the main findings for chronic illnesses. In panel $\mathrm{A}$ of table 7 , we show the estimates derived by the pooled binary Logit model, while in panel B the fixed effects Logit results are reported for the four samples mentioned earlier. The MWTP values in panel A range between 16.00-18.00 TL per month, while the MWTP for noise pollution reduction is 13.74 per month in the movers for other reasons in column (4). However, in panel B the MWTP values are significantly higher, almost doubled, showing the bias derived by the pooled regressions. Moreover, we estimated an instrumental binary Probit model with random effects, using the regional complaint rates and wind direction as instruments. We find that the MWTP values are similar with those found from the fixed effects Logit model. The coefficients for the remained determinants are not displayed, because the concluding remarks are the same with those derived earlier in the health status regressions.

Table: 7

\begin{tabular}{|c|c|c|c|c|}
\hline $\begin{array}{c}\text { Pooled and Pan } \\
\text { Model } \\
\text { Variables }\end{array}$ & $\underset{(1)}{\text { litional Fix }}$ & $\begin{array}{l}\text { ects Logit } \\
\text { (2) } \\
\text { Panel A: P }\end{array}$ & for Chr & llnesses \\
\hline Household Income & $\begin{array}{c}-0,1552 * * * * \\
(0,0155)\end{array}$ & $\begin{array}{c}-0,1517 * * * * \\
(0,0177)\end{array}$ & $\begin{array}{c}-0,0964 * * * \\
(0,0240)\end{array}$ & $\begin{array}{c}-0,1749^{* * * *} \\
(0,0329)\end{array}$ \\
\hline Air Pollution & $\begin{array}{c}0,2445 * * * \\
(0,0199)\end{array}$ & $\begin{array}{c}0,2343 * * * \\
(0,0230)\end{array}$ & $\begin{array}{l}0,1310^{*} \\
(0,0722)\end{array}$ & $\begin{array}{c}0,2797 * * * \\
(0,0404)\end{array}$ \\
\hline Noise Pollution & $\begin{array}{c}0,2448 * * * \\
(0,0226)\end{array}$ & $\begin{array}{c}0,2693 * * * \\
(0,0263)\end{array}$ & $\begin{array}{c}0,1507 \\
(0,1062)\end{array}$ & $\begin{array}{c}0,1667 * * * \\
(0,0457)\end{array}$ \\
\hline Number of Observations & 112,338 & 84,640 & 747 & 26,937 \\
\hline LR Chi Square & $\begin{array}{c}18,192,63 \\
{[0,000]}\end{array}$ & $13,987,61[0,000]$ & $\begin{array}{l}206,32 \\
{[0,000]}\end{array}$ & $\begin{array}{c}4,147,24 \\
{[0,000]}\end{array}$ \\
\hline $\begin{array}{c}\text { Pseudo R Square } \\
\text { MWTP }\end{array}$ & $\begin{array}{c}0,1506 \\
(17,58 ; 18,00) \\
\end{array}$ & $\begin{array}{c}0,1523 \\
(16,05 ; 17,63) \\
\end{array}$ & $\begin{array}{c}0,2474 \\
(17,03 ; 17,24)\end{array}$ & $\begin{array}{c}0,1479 \\
(18,72 ; 13,74) \\
\end{array}$ \\
\hline \multicolumn{5}{|c|}{ Panel B: Panel Fixed Effects Logit } \\
\hline Household Income & $\begin{array}{c}-0,1548^{* * * *} \\
(0,0219)\end{array}$ & $\begin{array}{c}-0,1755^{* * *} \\
(0,0251)\end{array}$ & $\begin{array}{l}-0,5263 \\
(0,5739)\end{array}$ & $\begin{array}{c}-0,1102^{* * *} \\
(0,0471)\end{array}$ \\
\hline Air Pollution & $\begin{array}{c}0,2582 * * * \\
(0,0273)\end{array}$ & $\begin{array}{c}0,2476 * * * \\
(0,0316)\end{array}$ & $\begin{array}{c}1,077 \\
(0,7123)\end{array}$ & $\begin{array}{c}0,2955^{* * *} * \\
(0,0560)\end{array}$ \\
\hline Noise Pollution & $\begin{array}{c}0,2504 * * * \\
(0,0308\end{array}$ & $\begin{array}{c}0,2770^{* * * *} \\
(0,0357)\end{array}$ & $\begin{array}{l}-0,5442 \\
(0,7776)\end{array}$ & $\begin{array}{c}0,1653^{* * *} * \\
(0,0629)\end{array}$ \\
\hline Number of Observations & 50,141 & 38,182 & 368 & 11,778 \\
\hline LR Chi Square & $6,742,80[0,000]$ & $5,167,78[0,000]$ & $\begin{array}{c}145,17 \\
{[0,000]}\end{array}$ & $\begin{array}{c}1,619,47 \\
{[0,000]}\end{array}$ \\
\hline $\begin{array}{c}\text { Pseudo R Square } \\
\text { MWTP }\end{array}$ & $\begin{array}{c}0,1774 \\
(37,07 ; 33,51) \\
\end{array}$ & $\begin{array}{c}0,1795 \\
(29,65 ; 32,59) \\
\end{array}$ & $\begin{array}{c}0,5201 \\
(36,49 ; 28,67) \\
\end{array}$ & $\begin{array}{c}0,1825 \\
(56,81 ; 32,16) \\
\end{array}$ \\
\hline
\end{tabular}

Standard errors between brackets, p-values between square brackets, ***and $* *$ indicates significance at $1 \%$ and $5 \%$ level. In column (1) the results refer to total sample, column (2) to non-movers, column (3) to movers for environmental reasons and column (4) to movers for other reasons.

In this study we used the LSA to calculate the MWTP for pollution reduction; however, the estimates show only by how much more the individuals are willing to pay rather than how much exactly are willing to pay. Therefore, the exact levels of air emissions and noise pollution should be considered. Overall, the results suggest that the main policies 
in Turkey should include the education reconstruction, health promotion and income distribution focusing on SES disparities elimination and reduction of income inequalities on health. Furthermore, the results confirm the argument of the International Energy Agency (2010), which suggests that Turkey should promote and implement the fuel switching from high-sulphur lignite and coal to natural gas and other alternative sources of energy.

However, there are major drawbacks in this study. First, the availability of panel data is required, in order to explore the relationship between health, pollution and other socioeconomic and demographic factors. Therefore, one major limitation of using repeated cross-sectional data is that we are not able to follow the same individuals over time. Nevertheless, repeated cross-sectional data suffer less from typical panel data problems like attrition and non-response. Furthermore, these problems are often substantially larger, both in number of individuals or households. Another drawback is that an individual may have "unobservable" attributes that are genetically inherited or acquired during childbirth that may influence a range of health and socio-economic outcomes. If we are unable to consider for these effects, then the observed association between health and income, and other characteristics might not reflect the true relationship. However, it is very difficult to find proper measures to use them as proxies, including the survey employed in this study.

\section{Conclusions}

This study used a set of repeated cross sectional and pseudo-panel micro-data on selfreported health status, chronic illness and air-noise pollution from the Income and Living Conditions Survey in Turkey. We applied various econometric approaches for robustness checks. The results showed that the MWTP for the individuals who report concerns about the environment is higher by 22-25 TL per month. In addition, most of the determinants examined in this study have significant effects on the health outcomes. We found that education is the most important factor followed by job status, marital status, house size and household type. The study examined also additional determinants, including the piped water, indoor flushing toilet and type of fuel for heating. We suggest for future research applications, the evaluation of air and noise pollution impact on groups, including urban versus rural areas, gender and age groups. Additionally, future surveys should be designed based on a more detailed geographical reference level that will allow a precise mapping of the pollution. Finally, future applications may examine the effects of environmental degradation on wage, productivity and working hours lost because of illness and poor health conditions.

\section{References}

Aecom (2011), "Wind Farm Noise Statutory Nuisance Complaint Methodology", Report Prepared for Defra, Contract No. NANR 277".

Aldwin, C. \& E. Greenberger (1987), "Cultural differences in the predictors of depression", American Journal of Community Psychology, 15(6), 789-813. 
Baetschmann, G. \& K.E. Staub \& R. Winkelmann (2015), "Consistent Estimation of the Fixed Effects Ordered Logit Model”, Journal of the Royal Statistical Society: Series A, 178(3), 685-703.

Basner, M. \& W. Babisch \& A. Davis \& M. Brink \& C. Clark \& S. Janssen \& S. Stansfeld (2014), "Auditory and non-auditory effects of noise on health", Lancet, 383, 1325-1332.

Beckett, M. \& M.N. Elliott (2002), "Does the Association between Marital Status and Health Vary by Sex, Race, and Ethnicity?", Rand, Labor and Population Program, Working Paper Series, 02-08.

Benzeval, M. \& J. Taylor \& K. Judge (2000), "Evidence on the relationship between low income and poor health: Is the Government doing enough?” Fiscal Studies, 21(3), 375-99.

Bostean, G. (2010), “An Examination of the Relationship between Family and U.S. Latinos' Physical Health. Field Actions Science Reports", Migration and Health, 2, 1-7.

Brunekreef, B. \& S.T. Holgate (2002), “Air pollution and health", Lancet, 360(9341), 1233-1242.

Currie, J. \& M. Neidell (2005), “Air Pollution and Infant Health: What Can We Learn from California's Recent Experience?”, The Quarterly Journal of Economics, 120(3), 100330 .

Deaton, A.S. (1985), "Panel Data from Time Series of Cross Sections", Journal of Econometrics, 30(1-2), 109-26.

Deaton, A.S. (2001), "Inequalities in Income and Inequalities in Health", in: F. Welch (ed.) The causes and consequences of increasing inequality, Chicago: Chicago University Press.

Deaton, A.S. (2002), "Policy Implications of the Gradient of Health and Wealth", Health Affairs, 21(2), 13-30.

Delfino, R.J. \& A.M. Murphy-Moulton \& M.R. Becklake (1998), "Emergency room visits for respiratory illnesses among the elderly in Montreal: association with low level ozone exposure", Environmental Research Section A, 76(2), 67-77.

Di Tella, R. \& R.J. MacCulloch (2007), "Gross National Happiness as an Answer to the Easterlin Paradox?", Journal of Development Economics, 86, 22-42.

Dockery, D. \& C.A. Pope \& X. Xiping \& J. Spengler \& J. Ware \& M. Fay \& B. Ferris \& F. Speizer (1993), "An Association between Air Pollution and Mortality in Six U.S. Cities", New England Journal of Medicine, 329(24), 1753-59.

Doornbos, M.M. (2001), "Professional support for family care-givers of people with serious and persistent mental illnesses", Journal of Psychosocial Nursing Mental Health Service, 39(12), 38-45.

Doygun, H. \& D.K. Gurun (2008), “Analysing and mapping spatial and temporal dynamics of urban traffic noise pollution: a case study in Kahramanmaras, Turkey", Environmental Monitoring and Assessment, 142(1-3), 65-72.

Erdogan, E. \& M. Yazgan (2009), "Landscaping in reducing traffic noise problem in cities: Ankara case", African Journal of Agricultural Research, 4(10), 1015-22.

Ferrer-i-Carbonell, A. \& P. Ve Frijters (2004), "How Important is Methodology for the estimates of the determinants of Happiness?", The Economic Journal, 114(497), 641-59.

Fraser, H. \& P. Eng (2012), Understanding and Reducing Noise Nuisance From Stationary Farm Equipment, Order N. 12-029 AGDEX 700.

Frey, B. \& S. Luechinger \& A. Stutzer (2010), "The life satisfaction approach to environmental valuation", Annual Review of Resource Economics, 2, 139-60. 
Gerking, S. \& R.L. Stanley (1986), “An Economic Analysis of Air Pollution and Health: The Case of St. Louis", The Review of Economics and Statistics, 68(1), 115-21.

Giovanis, E. \& O. Ozdamar (2016), "The Effects and Costs of Air Pollution on Health Status in Great Britain”, International Journal of Sustainable Economies Management, 5(1), 5267.

Greene, W. (2011), Econometric Analysis, Seventh Edition. Upper Saddle River, New Jersey: Prentice Hall.

Griefahn, B. (2002), "Sleep disturbances related to environmental noise”, Noise Health, 4(15), 5760.

Hamra, G.B. \& N. Guha \& A. Cohen \& F. Laden \& O. Raaschou-Nielsen \& J.M. Samet \& P. Vineis \& F. Forastiere \& P. Saldiva \& T. Yorifuji \& D. Loomis (2014), "Outdoor particulate matter exposure and lung cancer: a systematic review and meta-analysis", Environmental Health Perspectives, 122(9), 906-911.

Hoek, G. \& B. Brunekreef \& S. Goldbohm \& P. Fischer \& P.A. Van Den Brandt (2002), "Association between mortality and indicators of traffic-related air pollution in the Netherlands: a cohort study", Lancet, 360(9341), 1203-1209.

International Energy Agency (2010), "Energy Policies of IEA Countries", Turkey 2009 Review.

Istamto, T. \& D. Houthuijs \& E. Lebret (2014), "Willingness to pay to avoid health risks from road traffic-related air pollution and noise across five countries", Science of The Total Environment, 497-498, 420-429.

Janssen, N.A.H. \& J. Schwartz \& A. Zanobetti H.H. Suh (2002), “Air conditioning and sourcespecific particles as modifiers of the effect of PM10 on hospital admissions for heart and lung disease", Environmental Health Perspectives, 110(1), 43-9.

Laden, F. \& L.M. Neas \& D.W. Dockery \& J. Schwartz (2000), “Association of fine particulate matter from different sources with daily mortality in six US cities", Environmental Health Perspectives, 108(10), 941-47.

Levinson, A. (2012), "Valuing Public Goods Using Happiness Data: The Case of Air Quality", Journal of Public Economics, 96(9-10), 869-880.

Luechinger, S. (2009), "Valuing Air Quality Using the Life Satisfaction Approach", The Economic Journal, 119(536), 482-515.

Naeher, L.P. \& T.R. Holford \& W.S. Beckett \& K. Belanger \& E.W. Triche \& M.B. Bracken et al. (1999), "Healthy Women's PEF Variations with Ambient Summer Concentrations of $\mathrm{PM}_{10}, \mathrm{PM}_{2.5}, \mathrm{SO}_{4}{ }^{-2}, \mathrm{H}^{+}$, and $\mathrm{O}_{3}$ ", American Journal of Respiratory Critical Care Medicine, 160(1), 117-25.

Okuguchi, T. \& T. Osanai \& N. Fujiwara \& T. Kato \& N. Metoki \& Y. Konta \& K. Okumura (2002), "Effect of losartan on nocturnal blood pressure in patients with stroke: comparison with angiogenesis converting enzyme inhibitor", American Journal of Hypertension, 15(11), 998-1002.

O’Neill, M.S. \& D. Loomis \& V.H. Borja-Aburto (2004), “Ozone, area social conditions, and mortality in Mexico City”, Environmental Research, 94(3), 234-42.

Ovenden, N. \& S. Shaffer \& H. Fernando (2011), "How the weather affects the scale of urban noise pollution. Popular version of paper 2pNS3", Presented Tuesday Afternoon, May 24, 2011, 161 ${ }^{\text {st }}$ Acoustical Society of America Meeting, Seattle, Wash.

Ozer, S. \& H. Yilmaz \& M. Yesil \& P. Yesil (2009), "Evaluation of noise pollution caused by vehicles in the city of Tokat, Turkey", Scientific Research and Essays, 4(11), 1205-12. 
Ozyonar, F. \& I. Peker (2008), "Investigation of the environmental noise pollution in Sivas City Centre", Ecology, 18(69), 75-80.

Pedersen, M. \& L. Giorgis-Allemand \& C., Bernard \& I. Aguilera \& A.-M.N. Andersen \& F. Ballester, et al. (2013), "Ambient air pollution and low birthweight: a European cohort study (ESCAPE)", Lancet Respiratory Medicine, 1(9), 695-704.

Sisman, E.E. \& E. Unver (2011), "Evaluation of traffic noise pollution in Corlu, Turkey", Scientific Research and Essays, 6(14), 3027-33.

Tanrivermiş, H. (1998), "Willingness to Pay WTP and Willingness to Accept WTA Measures in Turkey: May WTP and WTA Be Indicators to Share the Environmental Damage Burdens: A Case Study", Journal of Economic Cooperation Among Islamic Countries, 19(3), 67-93.

Tekeşin, C. \& A. Shihomi (2014), "Measuring the Value of Mortality Risk Reductions in Turkey", International Journal of Environmental Research and Public Health, 11(7), 6890-922.

Turkish Statistical Institute (2013), Income and Living Conditions Survey Micro Data Set Cross Sectional, 2006-2012. Ankara.

Yilmaz, H. \& S. Ozer (2005), "Evaluation and analysis of environmental noise pollution in the city of Erzurum, Turkey", International Journal of Environmental Pollution, 23(4), 438-48.

Van Praag, B. \& A. Ferrer-i-Carbonell (2004), Happiness quantified: A satisfaction calculus approach, Oxford: Oxford University Press.

Verbeek, M. (2008), "Pseudo panels and repeated cross-sections”, in: L. Mátyás \& P. Sevestre (eds.), The Econometrics of Panel Data: Fundamentals and Recent Developments in Theory and Practice.

Welsch, H. (2002), "Preferences over prosperity and pollution: Environmental valuation based on happiness surveys", Kyklos, 55(4), 473-494.

Welsch, H. (2006), "Environment and happiness: Valuation of air pollution using life satisfaction data", Ecological Economics, 58, 801-813.

World Health Organization (2013), Review of evidence on health aspects of air pollution-REVIHAAP project. First results, WHO Regional Office for Europe, Copenhagen: Denmark.

World Health Organization (2014), "Methods and tools for assessing the health risks of air pollution local, national and international level", WHO Expert Meeting, Meeting Report Bonn, Germany, 12-13 May 2014, WHO Regional Office for Europe, Copenhagen: Denmark.

Zellner, A. (1962), “An efficient method of estimating seemingly unrelated regression equations and tests for aggregation bias", Journal of American Statistical Association, 57(298), 348-68.

Zellner, A. \& H. Theil (1962), “Three-stage least square: Simultaneous Estimation of simultaneous Equations", Econometrica, 301(1), 54-78. 